Transformasi : Jurnal Pendidikan Matematika dan Matematika

Volume 4, No. 2, Bulan Desember Tahun 2020, pp. 387-401

ISSN 2549-1164 (online)

Available online at https:/ / ejournal.unibabwi.ac.id/ index.php/ transformasi

\title{
ANALISIS KESALAHAN SISWA DALAM MENYELESAIKAN SOAL CERITA MATERI TEOREMA PYTHAGORAS
}

\author{
Wulan Permata Sari ${ }^{1}$, Lucy Asri Purwasi ${ }^{2}$, Yufitri Yanto ${ }^{3}$ \\ 1,2,3 Fakultas Keguruan dan Ilmu Pendidikan, STKIP PGRI Lubuklinggau \\ email korespondensi : asripurwasi@gmail.com
}

Diterima : (22-10-2020), Revisi: (12-12-2020), Diterbitkan : (24-12-2020)

\begin{abstract}
ABSTRAK
Penelitian ini bertujuan untuk mendeskripsikan jenis kesalahan yang dilakukan oleh siswa pada materi teorema pythagoras. Penelitian ini merupakan penelitian deskriptif kualitatif. Teknik pengumpulan data menggunakan triangulasi teknik dan sumber, yaitu berupa hasil tes dalam bentuk uraian sebanyak 3 soal, wawancara tidak berstuktur dan dokumentasi berupa buku catatan siswa dan LKS siswa. Sampel terdiri dari 24 siswa dengan kemampuan yang berbeda yaitu, rendah, tinggi dan sedang. Hasil penelitian ini diperoleh bahwa persentase rata-rata kesalahan konseptual siswa sebesar 99\% dalam kategori sangat tinggi, persentase rata-rata kesalahan prosedural siswa sebesar $63 \%$ dalam kategori tinggi, dan persentase rata-rata kesalahan komputasi siswa sebesar 82\% dalam kategori sangat tinggi.
\end{abstract}

Kata kunci: Analisis Kesalahan, Soal Cerita, Teorema Pythagoras.

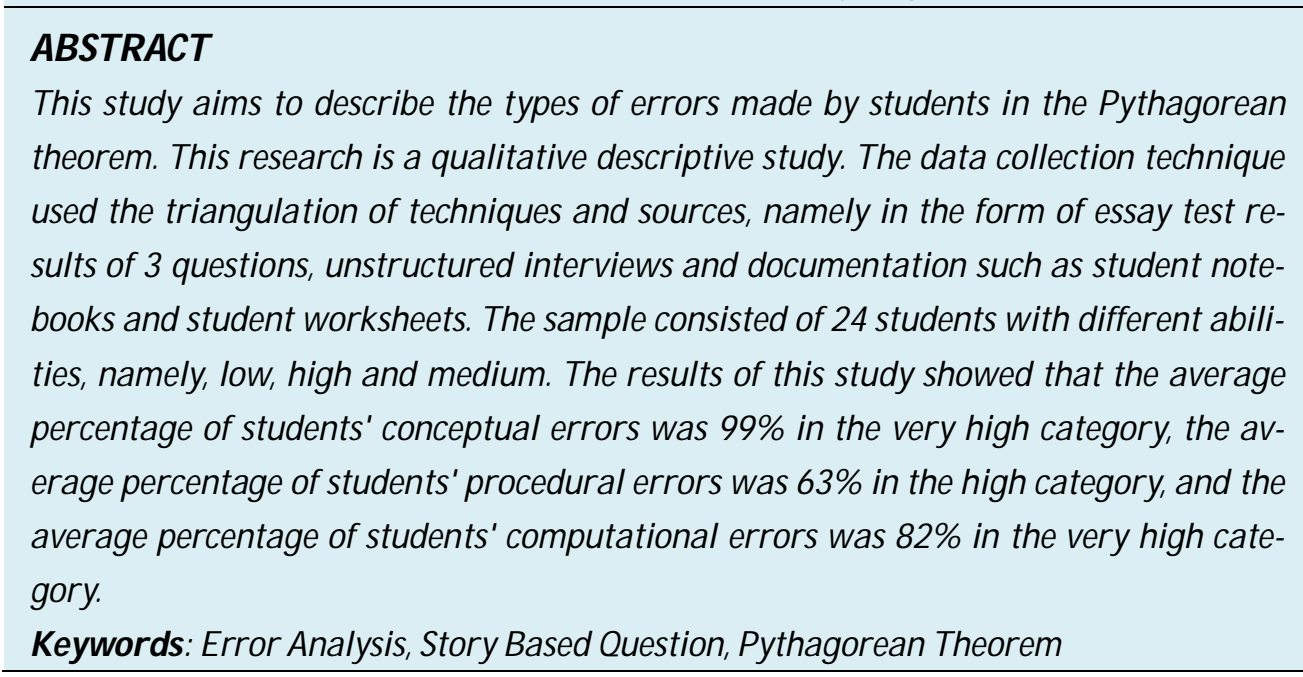

\section{Pendahuluan}

Pembelajaran matematika pada abad ke-21 memberikan tantangan tersendiri bagi para guru untuk selalu berinovasi dalam mengoptimalkan kualitas dan mutu pembelajaran di kelas (Purwasi, 2020). Matematika menjadi mata pelajaran yang 
penting dan wajib diajarkan pada jenjang sekolah dasar hingga perguruan tinggi, karena pembelajaran matematika dapat membekali siswa dengan kemampuan berfikir logis, analitis, sistematis, kritis, dan kreatif, serta kemampuan bekerjasama. Selain itu matematika juga sebagai sumber ilmu lain, dengan kata lain banyak ilmu yang penemuan dan pengembangannya tergantung dari matematika, sehingga mata pelajaran matematika sangat bermanfaat bagi siswa sebagai ilmu dasar untuk penerapan di bidang lain (Sholihah \& Mahmudi, 2015). Karena peran penting matematika bagi siswa, maka matematika diberi alokasi waktu dalam kurikulum 2013 sebesar lima jam pelajaran setiap minggunya (Dewi, 2016).

Mengingat pentingnya peran matematika maka pengetahuan matematika harus dikuasai sedini mungkin oleh siswa. Namun, pada umumnya siswa menganggap matematika menjadi salah satu pelajaran paling sulit karena materi yang akan dipelajari memiliki kaitan yang kuat pada materi-materi sebelumnya, sehingga siswa harus menguasai konsep-konsep sebelumnya untuk bisa mengerjakan tingkatan soal lebih sulit (Rohmah, 2020). Artinya, konsep pembelajaran matematika memiliki keterkaitan pada materi yang telah dipelajari sebelumnya.

Menurut Evianti, dkk. (2019) kegiatan pembelajaran matematika tentu tidak akan terlepas dari masalah matematika. Masalah matematika dapat berupa soal non rutin, yaitu soal cerita yang membutuhkan penyelesaian yang melibatkan tingkat penalaran lebih lanjut (Zulyanty, 2019). Untuk mengukur kemampuan siswa dalam memahami konsep matematika biasanya digunakan soal-soal yang berbentuk cerita maupun soal-soal matematika yang berbentuk non-cerita (Gunawan, 2016). Soal bentuk cerita merupakan bentuk soal yang menggambarkan permasalahan matematika yang berkaitan dengan kehidupan nyata sehari-hari atau bisa juga menggambarkan masalah lainnya (Rudyanto, 2017).

TIMSS menyatakan bahwa di Indonesia siswa kesulitan dalam menyelesaikan soal cerita sehingga dalam menyelesaikan permasalahan berbentuk soal cerita banyak siswa yang melakukan kesalahan (Hasan et, al, 2019). Lebih lanjut Hananta \& Ratu (2019) menyatakan bahwa siswa sering melakukan kesalahan dalam memahami persoalan matematika ataupun saat mengerjakan persoalan matematika. Kesulitan siswa terlihat dari kesalahan yang berbentuk kesalahan konsep, berhitung, pemahaman, dan cara berpikir logis serta matematis dalam menyelesaikan soal-soal matematika. 
Soal berbentuk cerita sering disajikan pada setiap pokok bahasan matematika, karena diperlukan permasalahan kontektual untuk mengaplikasikan konsep matematika tersebut. Salah satunya pada pokok bahasan teorema phytagoras. Teorema pythagoras merupakan salah satu materi yang harus dipelajari siswa pada kelas VIII. Menurut Ardiyanti\& Farihah (2019) siswa Sekolah Menengah Pertama (SMP) harus dapat memecahkan materi teorema pythagoras baik dalam bentuk model maupun aplikasi, karena teorema pythagoras banyak sekali digunakan dalam perhitungan bidang matematika yang lain.

Berdasarkan hasil wawancara dan observasi dengan salah satu guru matematika di kelas VIII-5 MTsN Kota Lubuklinggau, diperoleh informasi bahwa materi teorema pythagoras merupakan salah satu materi yang sulit dipahami oleh siswa sehingga siswa masih banyak melakukan kesalahan dalam mengerjakan soal teorema pythagoras. Penyebab kesalahan tersebut adalah kurangnya pemahaman siswa terhadap soal cerita, serta siswa malas mengerjakan soal cerita karena beranggapan bahwa materi teorema pythagoras itu sulit. Sehingga ketika dihadapkan dengan permasalahan teorema pythagoras, siswa akan merasa takut, terbebani, dan tidak percaya diri dalam memecahkan masalah tersebut. Hal tersebut dibuktikan dengan nilai ulangan harian siswa pada materi teorema pythgoras yang masih dibawah kriteria ketuntasan minimum (KKM), yaitu 70. Sedangkan rata-rata nilai ulangan harian terendah diperoleh oleh siswa kelas VIII-5, yaitu 65. Menurut guru matematika masalah mendasar yang paling mempengaruhi banyaknya kesalahan-kesalahan yang dilakukan oleh siswa adalah kesalahan konsep dan perhitungan dalam mengaplikasikan soal cerita.

Terdapat hasil penelitian yang relevan terkait kesalahan siswa dalam menyelesaikan soal cerita teorema pythagoras. Hasil penelitian Mulyanti, dkk. (2018) menunjukkan bahwa siswa kelas IX di Kota Cimahi masih memiliki tingkat kemampuan pemecahan masalah pada materi teorema Phytagoras yang tergolong rendah. Hasil penelitian Hasan, dkk. (2019) menunjukkan adanya : (1) kesalahan konseptual subjek dalam menggambar segitiga siku-siku dan menentukan sisi miringnya; (2) kesalahan prosedural yang dilakukan subjek dalam penarikan akar pada ruas kanan sementara ruas kiri masih berbentuk kuadrat; dan (3) kesalahan penghitungan/ komputasi subjek dalam menentukan hasil akar kuadrat dan selisih, sehingga salah dalam hasil akhir. Hasil penelitian Resliana \& Nurmeidina (2020) menunjukkan masih tingginya kesalahan siswa pada aspek konseptual, prosedural 
dan perhitungan pada soal teorema phythagoras. Berdasarkan beberapa penelitian yang telah dilakukan perlu dilakukan penelusuran dan tindakan melalui pemberian tes untuk melihat kesalahan yang dilakukan oleh siswa kelas VIII MTs N Kota Lubuklinggau dalam menyelesaikan soal cerita teorema phythagoras. Setelah mengetahui kesalahan siswa dalam menyelesaikan soal teorema phythagoras, guru dapat memberi penjelasan lebih lanjut dan detail pada materi tersebut agar kesalahan yang sama tidak terulang kembali (Rudyanto, 2017).

\section{Metode Penelitian}

Penelitian dilakukan menggunakan pendekatan kualitatif dengan jenis penelitian deskriptif, untuk menganalisis dan mendeskripsikan kesalahan siswa dalam menyelesaikan soal cerita materi teorema pythagoras. Subjek penelitian adalah 24 orang siswa kelas VIII-5 MTs N Lubuklinggau. Instrumen yang digunakan pada penelitian ini adalah tes, pedoman wawancara dan lembar observasi. Teknik pengumpulan data dilakukan dengan tes, wawancara, observasi dan dokumentasi. Tes terdiri dari tiga soal uraian yang memuat tipe kesalahan konseptual, prosedural dan komputasi/perhitungan. Tipe kesalahan yang digunakan dalam penelitian ini diadaptasi dari tipe kesalahan Hasan, dkk. (2019) yang disajikan pada tabel 1 .

Tabel 1.Tipe Kesalahan Siswa dalam Menyelesaikan Soal Cerita Teorema Pytagoras

\begin{tabular}{cccl}
\hline No & Tipe Kesalahan Siswa & & \multicolumn{1}{c}{ Indikator } \\
\hline 1. & Kesalahan Konseptual & a) & Salah mentransformasikan soal cerita ke dalam \\
& & bentuk geometri (segitiga siku-siku). \\
& & b) & Salah memodelkan permasalahan ke dalam \\
& & bentuk matematika. \\
& & c) & Salah menentukan rumus teorema pythagoras. \\
\hline 2. & Kesalahan Prosedural & a) & Salah menuliskan informasi yang diketahui dengan \\
& & lengkap. \\
& & b) & Salah mengerjakan sampai jawaban dengan selesai \\
& & & atau bentuk sederhana. \\
\hline 3. & Kesalahan Komputasi & Salah menentukan hasil operasi. \\
\hline
\end{tabular}

Bentuk wawancara yang digunakan adalah wawancara terstruktur dengan menggunakan pedoman wawancara sesuai dengan garis besar permasalahan yang akan ditanyakan pada guru dan siswa. Pedoman wawancara dibutuhkan agar pada 
saat proses wawancara, pertanyaan yang diberikan peneliti tidak keluar dari konteks permasalahan. Observasi dilakukan melalui proses pengamatan langsung pada siswa di sekolah. Ada 12 siswa yang menjadi subjek observasi dan wawancara yang masing-masing diperoleh dari kelompok tinggi, sedang dan rendah. Metode dokumentasi dilakukan dengan melihat dokumen pendukung dalam proses pembelajaran. Dokumen yang dikumpulkan berupa foto LKS, buku catatan siswa dan hasil tes yang diberikan kepada siswa tentang teorema pytagoras yang pernah dipelajari.

Analisis data yang digunakan dalam penelitian ini mengadaptasi dari model Miles dan Huberman (Sugiyono, 2016) yang berpendapat tentang aktivitas analisis data kualitatif yang dikerjakan secara interaktif dan berlangsung secara continuesampai selesai, sehingga datanya telah jenuh. Tahapannya terdiri dari, pengumpulan data, reduksi data, penyajian data, dan conclusion drawing/verification. Pengujian keabsahan data penelitian dilakukan dengan 4 tahapan uji, diantaranya :

(1) Uji Credibility

Uji kredibilitas yang dilakukan dengan teknik Triangulasi atau pengecekan data dari berbagai sumber dengan berbagai cara dan waktu. Dalam penelitian ini digunakan dua jenis triangulasi yaitu triangulasi teknik dan triangulasi sumber.

(2) Uji Transferability

Soal yang diberikan kepada siswa sudah divalidasi terlebih dahulu oleh validator dan guru matematika sehingga soal yang diberikan sudah dinyatakan valid dan layak digunakan.

(3) Uji Dependability

Uji dependability dilakukan melalui aktivitas penelitian pada tanggal 12 Mei 2020 dengan mengumpulkan data dilapangan bersama guru matematika kelas VIII-5.

(4) Uji Konfirmability

Hasil penelitian ini dikonfirmasikan kepada guru matematika dalam bentuk kesimpulan penelitian secara garis besar dan diperbolehkan untuk menampilkan hasil penelitian apa adanya. 


\section{Hasil dan Pembahasan}

Penelitian dilakukan tanggal 22 Juli 2020 sampai dengan 10 Agustus 2020. Adapun data persentase jawaban benar dan salah dari 24 orang siswa dapat dilihat pada tabel 2.

Tabel 2. Data Hasil Jumlah Benar dan Salah Jawaban Siswa

\begin{tabular}{ccccccc}
\hline Soal No & \multicolumn{2}{c}{ Konseptual } & \multicolumn{2}{c}{ Prosedural } & \multicolumn{2}{c}{ Komputasi } \\
\cline { 2 - 7 } & B & S & B & S & B & S \\
\hline 1 & 1 & 23 & 19 & 5 & 5 & 19 \\
\hline 2 & 0 & 24 & 0 & 24 & 0 & 24 \\
\hline 3 & 0 & 24 & 8 & 16 & 8 & 16 \\
\hline Jumlah & 1 & 71 & 27 & 43 & 13 & 59 \\
\hline Persentase & $1 \%$ & $99 \%$ & $37 \%$ & $63 \%$ & $18 \%$ & $82 \%$ \\
\hline
\end{tabular}

Adapun grafik persentase jawaban benar dan salah persentase kesalahan dari 24 orang siswa dapat dilihat pada gambar 1.

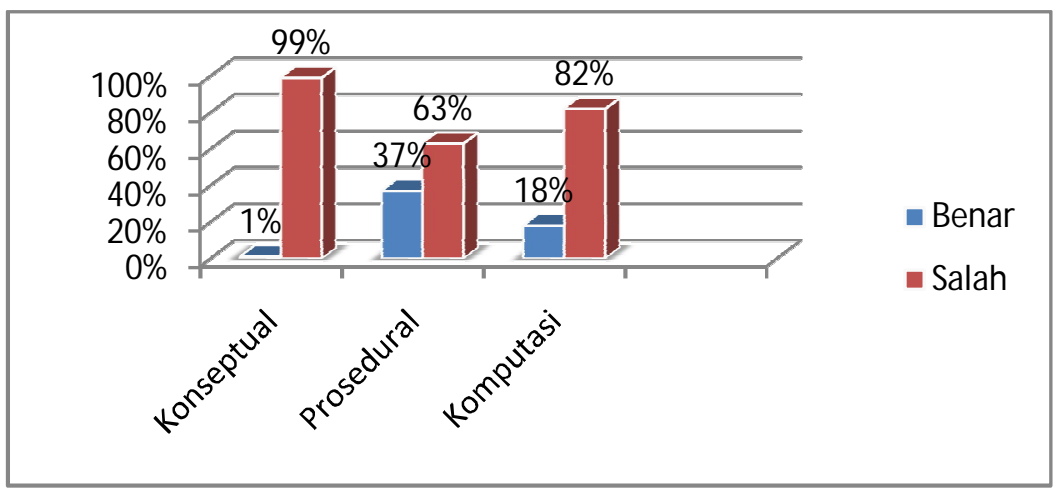

Gambar 1. Grafik Persentase Jawaban Benar Dan Salah Siswa

\section{Analisis Kesalahan Konseptual Siswa Pada Soal Nomor 1}

Soal nomor 1 dapat dilihat pada gambar 2 .

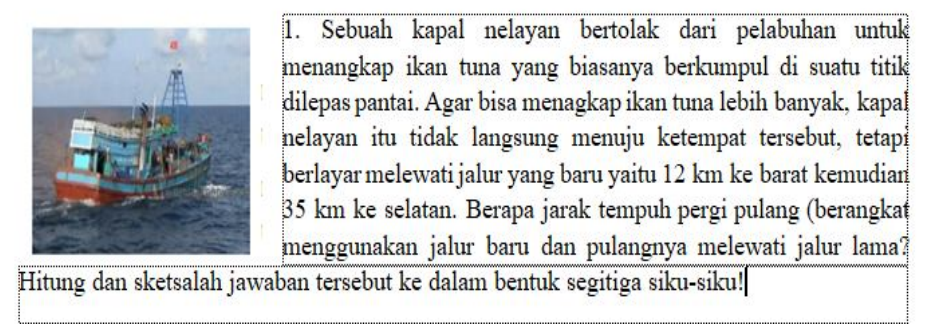

Gambar 2. Soal Nomor 1

Hasil tes subjek dengan kemampuan sedang (S-27) pada soal nomor 1 terdapat pada gambar 3 . 


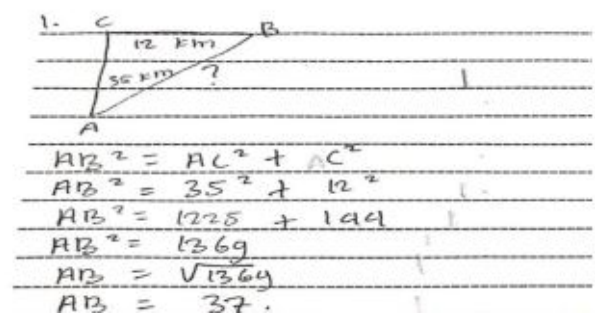

Gambar 3. Hasil Tes Subjek S-27 pada Soal Nomor 1

Sedangkan hasil wawancara dengan subjek S-27 adalah sebagai berikut.

\begin{tabular}{|l|c|l|}
\hline $\mathrm{P}$ & $:$ & $\begin{array}{l}\text { Kenapa kamu tidak memodelkan permasalahan dahulu kedalam bentuk } \\
\text { matematikanya nak? }\end{array}$ \\
\hline $\mathrm{S}-27$ & $:$ & Biasanya saya langsung kerjakan bu \\
\hline $\mathrm{P}$ & $:$ & Dilihat dari gambar yang kamu sketsakan $\mathrm{AB}, \mathrm{AC}$, dan $\mathrm{BC}$-nya berapa? \\
\hline $\mathrm{S}-27$ & $:$ & $\begin{array}{l}\text { Karena saya pakai rumus pythagoras jadi } \mathrm{AB} \text {-nya sisi miringnya bu untuk } \\
\text { mengetahui sisi miring maka saya tulis } A B^{2}=A C^{2}+B C^{2}\end{array}$ \\
\hline $\mathrm{P}$ & $:$ & $\begin{array}{l}\text { Nah, sekarang coba kamu lihat apakah kamu menggunakan rumus dengan } \\
\text { benar. }\end{array}$ \\
\hline $\mathrm{S}-27$ & $:$ & Oh, iya bu saya salah tulis rumusnya. \\
\hline $\mathrm{P}$ & $:$ & $\begin{array}{l}\text { nah, lain kali kamu tulis dahulu model permasalahannya kedalam } \\
\text { matematika. }\end{array}$ \\
\hline
\end{tabular}

Berdasarkan hasil tes dan wawancara dengan subjek S-27 diketahui bahwa subjek melakukan kesalahan konseptual dengan tidak memodelkan permasalahan ke dalam bentuk matematika dahulu atau menulis apa yang diketahui dalam soal, seperti $A B=$ nilai $A B, A C=$ nilai $A C$, dan $B C=$ nilai $B C$, sehingga tidak salah saat menuliskan rumusnya.

Hasil tes subjek dengan kemampuan rendah (S-30) pada soal nomor 1 terdapat pada gambar 4 .

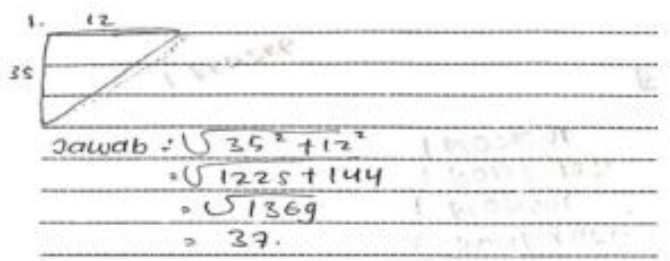

Gambar 4. Hasil Tes Subjek S-30 pada Soal Nomor 1

Sedangkan hasil wawancara dengan subjek S-30 adalah sebagai berikut.

\begin{tabular}{|l|c|l|}
\hline $\mathrm{P}$ & $:$ & Kenapa kamu tidak menuliskan rumus dahulu nak? \\
\hline S-30 & $:$ & Saya ketahui dari soalnya bu. \\
\hline $\mathrm{P}$ & $:$ & Bagaimana kamu bisa mensketsakannya nak? \\
\hline S-30 & $:$ & Karena dari soal ditanyakan jalur baru dan jalur lama menggunakan rumus \\
\hline
\end{tabular}




\begin{tabular}{|l|l|l|}
\hline & & teorema pytagoras $c^{2}=a^{2}+b^{2}$. \\
\hline $\mathrm{P}$ & $:$ & $\begin{array}{l}\text { Nah, menggapa kamu tidak menuliskan model matematikanya serta } \\
\text { menggapa kamu tidak tulis rumus yang digunakan? }\end{array}$ \\
\hline $\mathrm{S}-30$ & $:$ & biasanya saya langsung jawab seperti itu bu. \\
\hline $\mathrm{P}$ & $:$ & lain kali nulisnya harus lengkap ya \\
\hline
\end{tabular}

Berdasarkan hasil tes dan wawancara dengan subjek S-30 diketahui bahwa subjek melakukan kesalahan tidak menuliskan rumus walaupun subjek mengerti maksud soal. Karena kuran teliti maka S-30 tidak menuliskan rumus sisi miring $c^{2}=a^{2}+b^{2}$.

Hasil dokumentasi yang diperoleh dalam bentuk buku catatan siswa dan sumber belajar (LKS) menunjukkan bahwa pada catatan siswa tidak terdapat latihan yang memodelkan permasalahan dalam bentuk matematika, seperti pada gambar 5 .

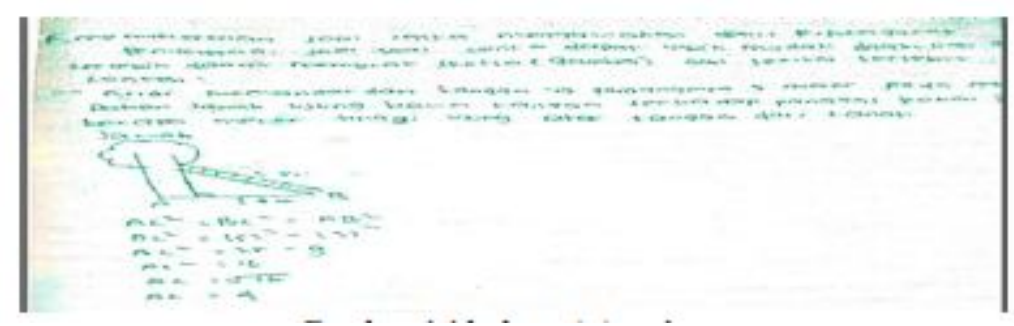

Gambar 5. Buku Catatan Siswa

Akibatnya siswa terbiasa menjawab soal tanpa memodelkan bentuk matematika terlebih dahulu.

Adapun LKS yang dimiliki siswa (pada materi teorema Pythagoras) tidak memuat contoh soal cerita yang menunjukkan pemodelan masalah dalam bentuk matematika. Hal ini membuat siswa salah secara konseptual.

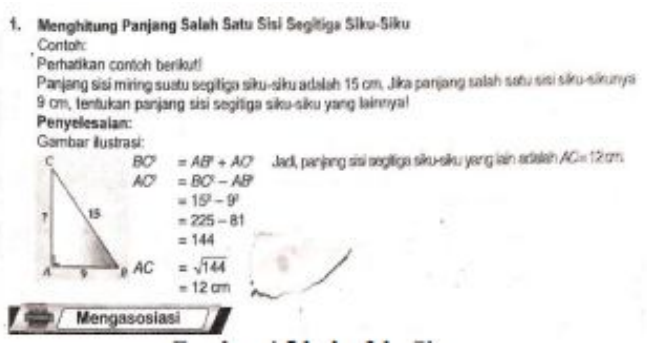

Gambar 6. LKS pada Materi Teorema Pythagoras

Gambar 6 menunjukkan latihan soal cerita pada materi teorema Pythagoras yang tidak memuat pemodelan matematika. Sehingga siswa terbiasa menjawab soal cerita materi teorema Pythagoras tanpa memodelkan ke bentuk matematika 
terlebih dahulu. Sementara pemodelan ke bentuk matematika merupakan tahapan konseptual.

Berdasarkan hasil wawancara dengan subjek diketahui bahwa penyebab tingginya persentase kesalahan siswa pada tipe konseptual bersumber dari catatan siswa yang menunjukkan hasil latihan soal cerita materi teorema pytagoras tidak memuat proses memodelkan permasalahan ke bentuk matematika. Selain itu contoh soal pada LKS sebagian besar juga menyajikan penyelesaian secara langsung tanpa ada proses memodelkan matematika. Akibatnya siswa terbiasa dengan proses penyelesaian secara langsung.

\section{Analisis Kesalahan Prosedural Siswa Pada Soal Nomor 2}

Soal nomor 2 dapat dilihat pada gambar 7.
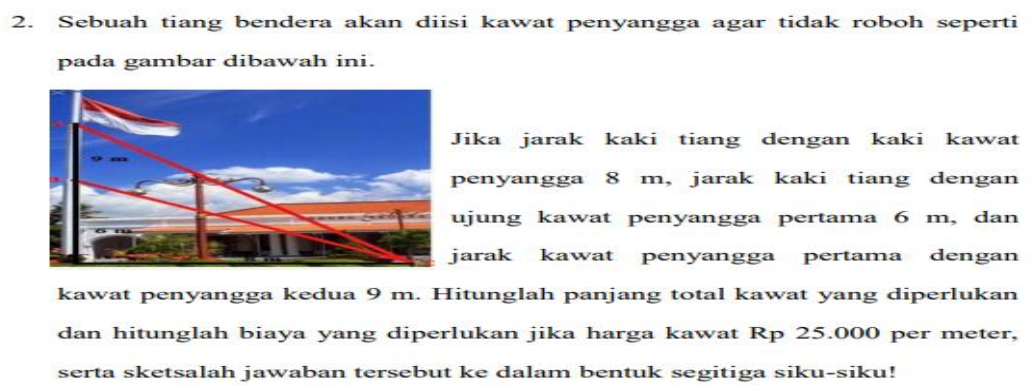

Gambar 7. Soal Nomor 2

Hasil tes subjek dengan kemampuan sedang (S-31) pada soal nomor 2 terdapat pada gambar 8 .

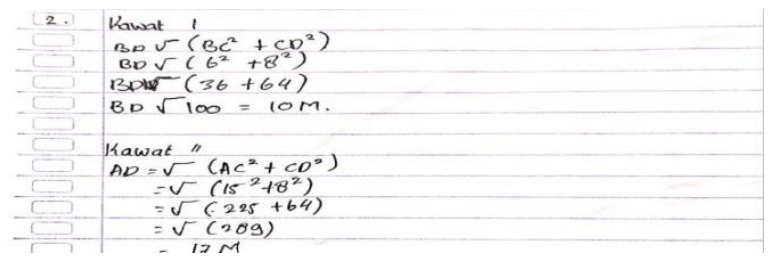

Gambar 8. Hasil Tes Subjek S-31 pada Soal Nomor 2

Sedangkan hasil wawancara dengan subjek S-31 adalah sebagai berikut.

\begin{tabular}{|l|l|l|}
\hline $\mathrm{P}$ & $:$ & Kenapa kamu buat kawat 1 dan kawat 2? \\
\hline S-31 & $:$ & $\begin{array}{l}\text { Karena di dalam soal terdapat kaki tiang dengan kawat pertama dan kaki } \\
\text { tiang dengan kawat kedua jadi saya buat aja kaki tiang pertama dan kaki } \\
\text { tiang kedua. }\end{array}$ \\
\hline $\mathrm{P}$ & $:$ & $\begin{array}{l}\text { Kenapa tidak kamu totalkankan jumlah kawat pertama + jumlah kawat } \\
\text { kedua? }\end{array}$ \\
\hline S-31 & $:$ & Iya bu , karena saya kurang paham dengan langkah-langkah berikutnya. \\
\hline
\end{tabular}




\begin{tabular}{|l|l|l|}
\hline P & $:$ & $\begin{array}{l}\text { Seharusnya kamu baca dengan teliti yang diminta oleh soal biaya yang } \\
\text { dibutuhkan kawat, jadi kamu totalkan dulu panjang kawatnya berapa } \\
\text { kemudian kamu kalikan dengan harga yang ada pada soal sehingga kamu } \\
\text { dapat biayanya. }\end{array}$ \\
\hline S-31 & $:$ & iya bu, saya paham. \\
\hline
\end{tabular}

Berdasarkan hasil tes dan wawancara dengan subjek S-31 diketahui bahwa subjek tidak memberikan jawaban hingga hasil akhir karena tidak paham dengan langkah selanjutnya.

Hasil tes subjek dengan kemampuan rendah (S-33) pada soal nomor 2 terdapat pada gambar 9 .

\begin{tabular}{|c|c|c|}
\hline$A^{2}=8^{2}+15$ & $T$ & $b=4$ \\
\hline$A^{2}=64+2$ & 5 & $s=14$ \\
\hline$A=\sqrt{289}$ & $\therefore 1$ & \\
\hline$A=17$ & 1 & \\
\hline
\end{tabular}

Gambar 9. Hasil Tes Subjek S-33 pada Soal Nomor 2

Sedangkan hasil wawancara dengan subjek S-33 adalah sebagai berikut.

\begin{tabular}{|l|c|l|}
\hline $\mathrm{P}$ & $:$ & Kenapa kamu menjawab $A^{2}=8^{2}+15^{2}$ ? \\
\hline S-33 & $:$ & $\begin{array}{l}\text { Saat saya baca soal saya langsung menjawab dengan rumus teorema } \\
\text { pythagoras bu 8 dari jarak kaki tiang lalu dapat hasil 15 saya jumlahkan dari } \\
\text { kaki tiang ujung kawat } 6 \text { dan jarak jarak kawat pertama serta kedua sehingga } \\
\text { didapatlah 15 bu. }\end{array}$ \\
\hline $\mathrm{P}$ & $:$ & $\begin{array}{l}\text { coba kamu baca lagi itu kan ada kaki kawat pertama dan kaki kawat kedua } \\
\text { nah kamu cari dahulu hasil kaki kawat pertama berapa dan kaki kawat kedua } \\
\text { berapa sehingga diperoleh total kawatnya. }\end{array}$ \\
\hline S-33 & $:$ & Jadi, saya harus pisahkan ya bu. \\
\hline $\mathrm{P}$ & $:$ & iya. \\
\hline
\end{tabular}

Berdasarkan hasil tes dan wawancara dengan subjek S-33 diketahui bahwa subjek sudah paham dengan konsep teorema Pythagoras tetapi salah dalam memahami soal, sehingga mengalami kesalahan dalam langkah penyelesaian soal tersebut.

Hasil dokumentasi yang diperoleh dalam bentuk buku catatan siswa dan sumber belajar (LKS) menunjukkan bahwa pada catatan siswa terdapat tahapan prosedural dalam contoh soal yang diberikan oleh guru. Hal itu tampak pada gambar 10 dalam latihan soal di buku catatan siswa terdapat jawaban yang benar dalam proses penentuan akar. Namun karena siswa tidak terbiasa dihadapkan pada soal cerita terkait materi teorema Pythagoras maka siswa tidak paham hingga salah dalam penyelesaian tahapan prosedural. 


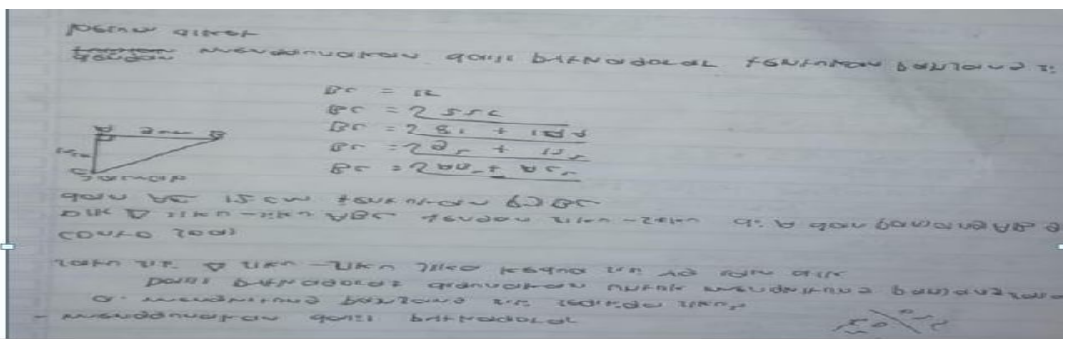

Gambar 10. Buku Catatan Siswa

Sebagian siswa memberikan jawaban yang benar pada soal tipe prosedural karena di dalam LKS memuat contoh soal dengan jawaban menggunakan proses penentuan akar yang benar, seperti pada gambar 11 .

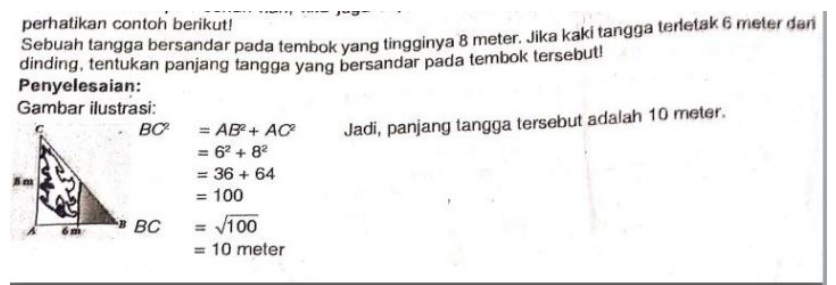

Gambar 11. LKS pada Contoh Soal Materi Teorema Pythagoras

Gambar 11 menunjukkan contoh soal cerita pada materi teorema Pythagoras yang memuat prosedural. Sehingga siswa terbiasa dalam menyelesaikan proses penentuan akar secara prosedural.

Berdasarkan hasil wawancara dengan beberapa subjek diketahui bahwa penyebab tingginya persentase siswa menjawab benar pada soal tipe prosedural karena siswa terbiasa menjawab soal yang terkait proses penentuan akar. Hal ini tampak pada latihan soal dalam catatan siswa dan contoh soal dalam LKS yang memuat penyelesaian dengan proses melatih indikator ketepatan siswa dalam menggunakan prosedural.

\section{Analisis Kesalahan Komputasi Siswa pada Soal Nomor 3}

Soal nomor 3 dapat dilihat pada gambar 12.

3. Dua buah tiang berdampingan berjarak $24 \mathrm{~m}$. jika tinggi tiang masing-masing adalah $22 \mathrm{~m}$ dan $12 \mathrm{~m}$. hitunglah panjang kawat penghubung anatara ujung tiang tersebut dan sketsalah jawaban tersebut ke dalam bentuk segitiga sikusiku!

Gambar 12. Soal Nomor 3

Hasil tes subjek dengan kemampuan rendah (S-15) pada soal nomor 3 terda- 
pat pada gambar 13 .

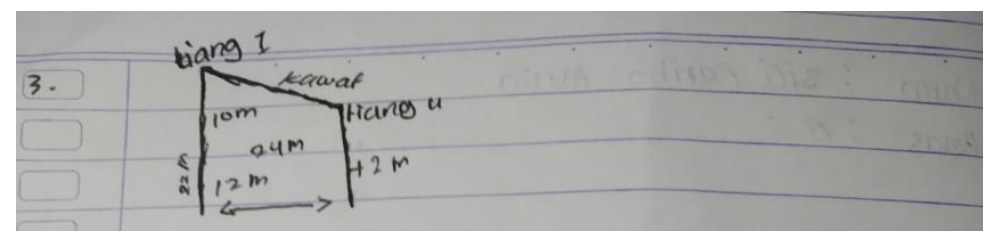

Gambar 13. Hasil Tes Subjek S-15 pada Soal Nomor 3

Sedangkan hasil wawancara dengan subjek S-15 adalah sebagai berikut.

\begin{tabular}{|l|c|l|}
\hline $\mathrm{P}$ & $:$ & kenapa hasil nomor 3 kamu hanya sketsa nak? \\
\hline S-15 & $:$ & saya hanya ngerti buat sketsanya aja bu. \\
\hline $\mathrm{P}$ & $:$ & $\begin{array}{l}\text { coba kamu perhatikan gambar yang kamu buat, disanakan ada tinggi kawat } \\
\text { ke 1 dan tinggi kawat kedua nah langkah selanjutnya kamu hitung tinggi } \\
\text { kawat ke 1 dengan rumus teorema pythagoras begitu juga untuk kawat } \\
\text { kedua. }\end{array}$ \\
\hline S-15 & $:$ & iya bu, saya selalu bingung dengan menggunakan rumus teorema pythagoras. \\
\hline
\end{tabular}

Berdasarkan hasil tes dan wawancara dengan subjek S-15 diketahui bahwa subjek melakukan kesalahan komputasi karena tidak menghitung hasil akhir. Subjek hanya mencoba membuat sketsa dari permasalahan karena subjek bingung dalam penggunaan rumus. Sehingga tidak dapat melanjutkan ke tahap berikutnya pada soal tipe komputasi.

Hasil dokumentasi yang diperoleh dalam bentuk buku catatan siswa dan sumber belajar (LKS) menunjukkan bahwa pada catatan siswa terdapat banyak kesalahan di bagian komputasi. Siswa terbiasa langsung menghitung hasil akhir dari bilangan dalam akar tanpa ada tahapan komputasi. Hal ini dapat diketahui pada catatan siswa seperti pada gambar 14 .

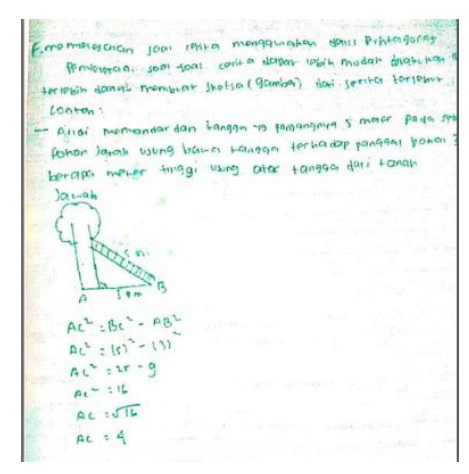

Gambar 14. Buku Catatan Siswa

Gambar 14 menunjukkan contoh soal cerita yang jawabannya benar dalam proses penentuan akar sehingga membuat siswa mudah dalam menghitung hasil akhirnya 
saja tanpa melalui proses komputasi.

Siswa dikatakan memiliki kesalahan tinggi pada soal tipe komputasi karena dalam LKS terdapat contoh soal cerita yang memuat jawaban tanpa tahapan komputasi. Hal tersebut menyebabkan siswa salah dalam menentukan hasil akhir seperti pada gambar 15 .

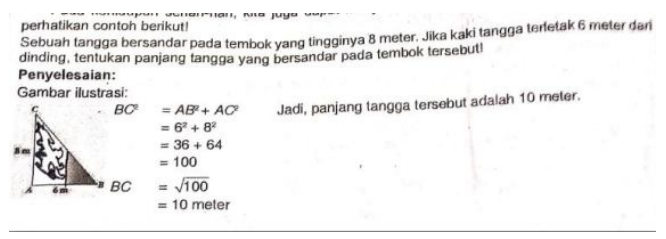

Gambar 15. LKS pada Contoh Soal Materi Teorema Pythagoras

Berdasarkan hasil analisis sumber belajar milik subjek diketahui bahwa contoh soal cerita dalam materi teorema Pythagoras memiliki penyelesaian yang memuat operasi hitung tanpa tahapan komputasi.

\section{Pembahasan}

Hasil analisis data tes yang dilakukan terhadap 24 siswa menunjukkan persentase kesalahan konseptual sebesar 99\%, kesalahan prosedural sebesar 63\%, dan kesalahan komputasi sebesar 63\%. Siregar (2019) menyatakan bahwa kesalahan prosedural yang dilakukan siswa terjadi karena tidak dapat menyusun makna kata yang dipikirkan, kurang teliti dalam memahami soal, kurang memiliki kemampuan matematika, kurang latihan mengerjakan soal-soal bentuk-bentuk soal cerita serta kurang memahami soal. Sedangkan Yadrika (2019) menyatakan bahwa siswa berkemampuan tinggi lebih dominan melakukan kesalahan konsep sebesar 20\% jika dibandingkan dengan kesalahan lainnya. Hal ini dapat terjadi karena siswa kurang teliti dalam menyelesaikan soal. Siswa terlalu terburu-buru untuk menyelesaikan soal yang diberikan dan menyebabkan komputasi yang dilakukan tidak tepat. Sedangkan siswa dengan kemampuan sedang dan rendah kebanyakan melakukan kesalahan konsep, bahkan masih banyak konsep-konsep yang belum dipahami siswa.

\section{Kesimpulan}

Berdasarkan hasil penelitian, analisis data dan pembahasan yang telah diuraikan maka dapat disimpulkan bahwa jenis-jenis kesalahan yang dilakukan siswa dalam menyelesaikan soal cerita teorema pythagoras terdiri dari kesalahan konseptual, 
prosedural, dan kesalahan komputasi. Kesalahan yang dilakukan oleh siswa kelas VIII 5 MTs N Lubuklinggau dalam materi teorema pythagoras menunjukkan persentase kesalahan konseptual sebesar 99\%, kesalahan prosedural sebesar 63\%, dan kesalahan komputasi sebesar 63\%. Kesalahan konseptual dilakukan siswa dalam mentransformasikan soal cerita kedalam bentuk segitiga siku-siku, memodelkan permasalahan ke bentuk matematika, dan menentukan rumus teorema Pythagoras. Kesalahan prosedural dilakukan siswa dalam menuliskan informasi yang diketahui dengan lengkap dan menyelesaikan soal hingga bentuk akhir yang paling sederhana. Kesalahan komputasi dilakukan siswa dalam menentukan hasil operasi.

\section{Daftar Pustaka}

Ardiyanti, S. A., \& Farihah, U. (2019). Analisis Kesulitan Siswa dalam Menyelesaikan Soal Cerita pada Materi Teorema Pythagoras Ditinjau dari Pemecahan Masalah Polya. Prosiding Seminar Pendidikan Matematika, pp 389-398.

Dewi, E. P. (2016). Identifikasi Kesalahan dalam Menyelesaikan Soal Cerita Materi Lingkaran Siswa Kelas VIII E SMP N 1 Srandakan. Skripsi: Tidak diterbitkan.

Evianti, N., Jafar, Busnawir, \& Masi, L. (2019). Analisis Kesalahan Siswa Kelas IX MTis Negeri 2 Kendari dalam Menyelesaikan Soal-Soal Lingkaran. Jurnal Pendidikan Matematika, 10(2), 138-149.

Gunawan, A. (2016). Analisis Kesalahan dalam Menyelesaikan Soal Cerita pada Mata Pelajaran Matematika Siswa Kelas V SDN 59 Kota Bengkulu. Jurnal PGSD: Jurnal Ilmiah Pendidikan Guru Sekolah Dasar, 9 (2), 216-225.

Hananta, F. I., \& Ratu, N. (2019). Analisis Kesalahan Siswa dalam Menyelesaikan Soal Logaritma. Jurnal Pendidikan Matematika Indonesia, 4(1), 29- 35.

Hasan, N., Subanji, \& Sukorianto. (2019). Analisis Kesalahan Siswa Kelas VIII dalam Menyelesaikan Soal Cerita Terkait Teorema Pythagoras. Jurnal Pendidikan: Teori, Penelitian, dan Pengembangan, 4(4), 468-477.

Mulyanti, N. R., Yani, N., \& Amelia, R. (2018). Analisis Kesulitan Siswa dalam Pemecahan Masalah Matematik Siswa SMP Pada Materi Teorema Phytagoras. Jurnal Pembelajaran Matematika Inovatif, 1(3), 415-426.

Purwasi, L. A. (2020). The Development of Higher Order Thinking Skill on Junior High School Students Through Guided Inquiry-Based Leraning Approach. 
Jurnal Pendidikan Matematika dan IPA, 11(2), 311-322.

Resliana, E. D., \& Nurmeidina, R. (2020). Analisis Kesalahan Siswa SMP dalam Menyelesaikan Soal Pemahaman Konsep Teorema Phytagoras. Prosiding Konferensi Nasional Pendidikan, pp 18-23.

Rohmah, A. S. (2020). Analisis Kesalahan Siswa Mts dalam Menyelesaikan Soal pada Materi Teorema Pythagoras. Jurnal Pembelajaran Matematika Inovatif, 3(5), 433-442.

Rudyanto, H. E. (2017). Pengaruh Kemampuan Membaca Pemahaman Terhadap Prestasi Belajar Matematika pada Pokok Bahasan Soal Cerita Kelas IV. Jurnal Kependidikan Dasar Islam Berbasis Sains, 2(2), 43-50.

Sholihah, D. A., \& Mahmudi, A. (2015). Keefektifan Experiential Learning Pembelajaran Matematika Mts Materi Bangun Ruang Sisi Datar . Jurnal Riset Pendidikan Matematika, 2(2), 175-185.

Siregar, N. F. (2019). Analisis Kesalahan Siswa dalam Menyelesaikan Soal Matematika. Jurnal Ilmu-ilmu Pendidikan Sains, 7(01), 1-14.

Sugiyono. (2016). Metode Penelitian Pendidikan. Bandung: Alfabeta.

Yadrika, G. (2019). Analisis Kesalahan Siswa SMP dalam Menyelesaikan Soal pada Materi Teorema Pythagoras dan Lingkaran.JJPM, 12(2), 1-18.

Zulyanty, M. (2019). Newman Error Analysis Siswa Madrasah dalam Menyelesaikan Soal Cerita Matematika. Journal Cendekia: Jurnal Pendidikan Matematika, 3(2), 379-388. 